\title{
6 Casamento Sob a Mira da Autoria Feminina
}

Adriana Maria de Abreu Barbosa ${ }^{*}$

Doutora em Semiologia pela UFRJ. Professora Adjunta da Cadeira de Teoria da Literatura na Universidade Estadual do Sudoeste da Bahia.
Resumo: Estudo comparativo entre três contos de autoria feminina que objetiva apontar a presença da formação discursiva feminista na literatura brasileira pós década de sessenta. Apoiado nas teorias do discurso e na crítica feminista este artigo reconhece o gênero como categoria analítica e política e a literatura brasileira como lócus de tecnologia de gênero. Nas narrativas estudadas há denúncia da violência simbólica presente na constituição do casamento nos moldes patriarcais. Desse modo, estudar a literatura de autoria feminina é dar visibilidade a crítica social engendrada por mulheres escritoras.

Palavras-chave: Feminismo; Tecnologias de gênero; Literatura de autoria feminina.
Abstract: It is a comparative study of three tales written by women which aims to point out the presence of feminist discursive formation in Brazilian literature after the sixties. Supported by discourse theories and feminist criticism, this article recognizes gender as analytical and political category and Brazilian literature as the locus of gender technology. In the studied narratives there are denunciations of the symbolic violence present in the constitution of marriage in patriarchal fashion. Thus, studying women's writing is giving visibility to social criticism engendered by women writers.

Keywords: Feminism; Gender technologies; Women’s writing. 


\section{Introdução}

Por que ler textos de autoria feminina e não os clássicos? Num pastiche homenagem a Ítalo Calvino, procuro responder a esta pergunta pelas mãos de Virginia Woolf e o jogo imagético por ela proposto num ensaio intitulado Um teto todo seu. Valendo-se de uma ilustração hipotética, Woolf indaga o que teria acontecido se Shakespeare tivesse uma irmã e ela fosse talentosa na escrita e pressupõe um final trágico para mesma. A autora que viveu em tempos nos quais as meninas não eram incentivadas a completar os estudos, discute a invisibilidade das mulheres na cena cultural, não só neste ensaio como em tantos outros. E, desse modo, passa a ser referência para os estudos feministas.

No Brasil, a partir da década de oitenta cresce nas universidades um campo de pesquisa científica na área de Letras que busca revisar a historiografia literária de modo a estudar as autoras que não entraram no Cânone Literário. O fato é que canônicas ou não canônicas são muitas as escritoras na cena cultural brasileira e as pesquisas apontam nas obras dessas autoras profunda consciência de gênero e denúncia das relações desiguais entre homens e mulheres, assim como todo tipo de violência, inclusive, a simbólica. Desse modo, temos observado como os estudos feministas ao abordarem questões sobre identidades de gênero, relações de gênero e sexualidade em textos literários assinados por mulheres evidenciam nesses textos o material histórico sobre o que foram, o que são e o que podem vir a ser as relações de gênero no Brasil.

Além disso, os estudos de gênero numa abordagem cultural apontam como o aprendizado de uma cultura feminina (com enfoque no grupo, no coletivo, na solidariedade e nas relações mais simétricas e menos verticalização do poder, é algo que nos ajudaria a construir um projeto de educação por uma cultura da paz. Desse modo, retomar os ensinamentos deixados pela/através desta literatura-memória de mulheres brasileiras é um desejo político de intervenção na direção de uma educação que motive o autoconhecimento, a busca por relacionamentos menos desiguais e a convivência mais harmônica entre homens e mulheres independente de suas orientações sexuais.

Uma das escritoras renomadas brasileiras Marina Colasanti escreve em ensaio intitulado Rir pode não ser o melhor remédio (do livro Fragatas para terras distantes) uma denúncia sobre o tratamento que tem sido dado a temática do feminino pelas novas gerações no mundo editorial. A temática do feminino tratada pela geração pós década de sessenta com seriedade e como objeto 
científico, hoje, nos anos 2000, segundo a autora, é objeto das prateleiras de humor e auto-ajuda, conforme afirma Colasanti:

Estávamos, naqueles anos, descobrindo uma nova maneira de ser mulher ou, como disse Simone, estávamos nos fazendo mulheres. E a nova maneira de ser mulher era, então, sair daquele mundo lacrado ao qual havíamos estado confinadas, para conquistar o espaço maior do coletivo. Era pensar o feminino em termos sociais. E entrar nas livrarias e buscar a seção 'Mulher' equivalia a encontrar um entusiasmante encontro marcado de antropologia, sociologia, história, psicologia. O feminino parecia um continente novo onde tudo ainda estava por descobrir. Agora nos deleitamos com o diário de Bridget Jones multiplicado em infinitas variantes - havia uma inclusive naquela tal estante, mas atualizada, com diário on line. $\mathrm{E}$ trocamos os amplos espaços recém possuídos, pelo limitado espaço do ego. Um ego mais moderno é verdade, porque aberto à visitação pública. As seções 'Mulher' nem existem mais nas livrarias. Foram substituídas por 'Estudos de Gênero', em que as mulheres aparecem mais vinculadas a homossexualismo do que a qualquer outra coisa. $\mathrm{E}$ as mulheres foram transferidas para a seção 'Comportamento', uma vaga mistura de autoajuda e aconselhamento amoroso (COLASANTI, 2004, p. 191-194)
De autoria da mesma Colasanti temos o livro Contos de amor rasgados que, em prosa poética tecida em contos breves, nos idos de oitenta, perscruta o feminino como continente inexplorado, porque lacrado na vida privada. A obra da autora é para mim (leitora e feminista) um lócus para rever e repensar os papéis de gênero, mas, sobretudo, um lócus de denúncia a dominação patriarcal sobre os corpos e as vidas das mulheres e sua conseqüente violência simbólica. Volto a este livro, que costumo usar numa disciplina sobre estudos da narrativa, agora com intuito de apontar as contribuições do pensamento feminista para repensar nosso modo de estar no mundo e, principalmente, nossa relação com os outros. A outricidade, tema recorrente nos estudos de gênero (pois foi árduo aprendizado na cultura das mulheres, BARBOSA, 1999), pode ser uma estratégia em tempos de identidades líquidas, numa sociedade que realocou o discurso ético/político do quadro da sociedade justa para o dos direitos humanos e colocou em cena o indivíduo no lugar do cidadão (BAUMAN, 2001).

Concordando com Friedrich Engels que afirmou ter aprendido mais com o romancista Balzac sobre a sociedade francesa do que em todos os livros dos historiadores e economistas da época, eu também como leitora tenho escolhido autoras mulheres para me ajudarem a 
${ }^{1}$ As formações discursivas estão ligadas a formações ideológicas, que podem ser definidas como um conjunto de representações simbólicas que estabelecem relacõos com a posição dos sujeitos (HEINE, 2012, p. 28)

\section{Adriana Maria de Abreu Barbosa}

olhar o mundo sob a ótica do feminino. E em especial nas narrativas assinadas por mulheres analiso as histórias silenciadas pela história oficial, afinal, como nos orienta Ligia Leite (1987), “a ficção pode explodir a história do vencedor para iluminar retalhos da palavra e da ação daqueles que um dia foram impedidos de entrar para $O$ panteon dos seus heróis" (p. 85).

Portanto, escuto com atenção a denúncia de Colasanti sobre as novas publicações sobre e de mulheres e proponho comparar os minicontos da autora (já mencionados aqui) com os minicontos de Ana Miranda em Noturnos (1999) e os de Kátia Borges (2010) em Escorpião Escarlate. Afinal, como essas obras não são Best Sellers, pressupõe-se que as autoras não estão operando na lógica do mercado editorial e tem mais autonomia para criar fora dos ditames mercadológicos. Nessas narrativas vou ao encontro das formações discursivas ${ }^{1}$ feministas, buscando delinear fronteiras e dissonâncias sob os tópicos identidade e outricidade. Em linhas gerais procuro descobrir o que permanece e o que se altera em termos estéticos e temáticos nas narrativas dessas autoras na passagem do século XX ao XXI no que tange os conceitos de gênero e o ideário feminista. Acreditamos que esses discursos literários nos ajudam a entender e participar melhor deste mundo, já que nos desafiam a refletir sobre que mulheres e homens somos e quais queremos ser.

\section{Estudos de gênero e o ideário feminista}

Num texto rico de debate crítico sobre o conceito de gênero, intitulado Gênero: uma categoria útil para análise histórica, Joan Scott (1989) reconhece que o termo é herdeiro da onda feminista americana num tempo no qual houve necessidade de rejeitar o determinismo biológico insistindo no caráter fundamentalmente social das distinções baseadas no sexo. E embora o artigo de Scott de fato amplie e problematize o conceito, como historiadora que é, a autora não consegue atropelar o presente sem mapear o passado.

$\mathrm{Na}$ mesma direção das feministas americanas, a filósofa Simone de Beauvoir (e sua célebre frase Ninguém nasce mulher: torna-se) antecipa o conceito de gênero sem nomeá-lo. Antecipa também toda a discussão sobre identidades não fixas caras aos desconstrucionistas. Sendo assim, Beauvoir entra para o Cânone da Filosofia Ocidental e leva com ela o legado sobre a discussão acadêmico-científica do tema do feminino.

A construção de uma epistemologia própria para o tema do feminino tem sido alvo de críticas e muitas subdivisões em linhas 
teóricas como nos apresenta Joan Scott (1989). Sobre a fragilidade dessas discussões, no que concerne o estado de arte desta área de conhecimento, o texto de Scott lança muitas questões:

Se tratarmos da oposição entre masculino e feminino como sendo mais problemática do que conhecida, como alguma coisa que é definida e constantemente construída num contexto concreto, temos então que perguntar não só o que é que está em jogo nas proclamações ou nos debates que invocam o gênero para justificar ou explicar suas posições, mas também como percepções implícitas de gênero são invocadas ou reativadas. Qual é a relação entre as leis sobre as mulheres e o poder do Estado? Por que (e desde quando) as mulheres são invisíveis como sujeitos históricos, quando sabemos que elas participaram dos grandes e pequenos eventos da história humana? O gênero legitimou a emergência de carreiras profissionais? Para citar o título de um artigo recente da feminista francesa Luce Irigaray, o sujeito da ciência é sexuado? Qual é a relação entre a política do Estado e da descoberta do crime de homossexualidade? Como as instituições sociais têm incorporado o gênero nos seus pressupostos e na sua organização? Já houve conceitos de gênero realmente igualitários sobre os quais foram projetados ou mesmo baseados sistemas políticos? (p. 29)
Neste artigo, entretanto, parto do conceito de gênero conforme compila Guacira Louro (2010) para quem gênero é uma ferramenta analítica e também política e se refere "ao modo como as características sexuais são compreendidas e representadas" (p. 22). E entende "o gênero como constituinte da identidade de sujeitos, isto é algo que transcende o mero desempenho de papéis, a ideia é perceber o gênero fazendo parte do sujeito, constituindo-o". Nesta perspectiva admite-se que as diferentes instituições e práticas sociais são constituídas pelos gêneros e são, também, constituintes dos gêneros (p. 24-25).

Para Teresa de Lauretis (1994) a construção do gênero ocorre através das várias tecnologias do gênero e discursos institucionais com poder de controlar o campo do significado social e assim promover e implantar representações de gênero. Isto é, existem discursos autorizados e autoritários "dedicados à produção de homens e mulheres." Reconhecemos na Literatura um lócus para tecnologia de gênero, entretanto, baseada em pesquisas nos últimos 20 anos, suponho, por verificação, que a literatura de boa parte de escritoras mulheres no Brasil exerça um papel transgressor nessa construção, apontando falhas no padrão proposto pelas outras tecnologias (igreja, escola, família e mídias) do que seria o feminino 
2 Segundo Junqueira (2012), Heteronormatividade é um conjunto de estratégias que são materializadas através de pessoas por meio de discursos, valores, práticas, defendendo que a forma legítima e hegemônica de viver a sexualidade é a heterossexualidade, opondo-se a outras formas de manifestação sexual e também de gênero. exemplar. Neste sentido, a literatura seria um vetor de contracultura, possibilitando a emergência de novas representações do gênero ou, ao menos, uma crítica do status quo e, conseqüentemente, da heteronormatividade ${ }^{2}$ imposta pelo patriarcalismo.

As autoras que escrevem potencializando essa crítica estariam em consonância com a proposta feminista de desmascarar a hegemonia patrilinear e a dominação simbólica dela decorrente (BARBOSA, 2011c).

A noção de desigualdade entre os gêneros é um dos mitos herança do Patriarcado. A dicotomia essencialista, na qual o feminino era a ausência de razão, foi atacada pelo feminismo da diferença que tem na obra de Rosiska Darcy Oliveira (1993) fortuna crítica. No livro Elogio da diferença, Oliveira pauta-se no polêmico conceito de cultura feminina, "o projeto da diferença é, antes de mais nada, o reconhecimento de que o universo feminino existe, de que ele é fruto de um corpo que se fez experiência histórica e social, de um psiquismo que se fez cultura" (p.109).

Essa vertente do pensamento feminista se apropria da diferença para dar novo juízo de valor para as supostas características femininas que nada mais são do que um longo aprendizado. O feminismo da diferença revisita a ideia de essência para ressemantizá-la:

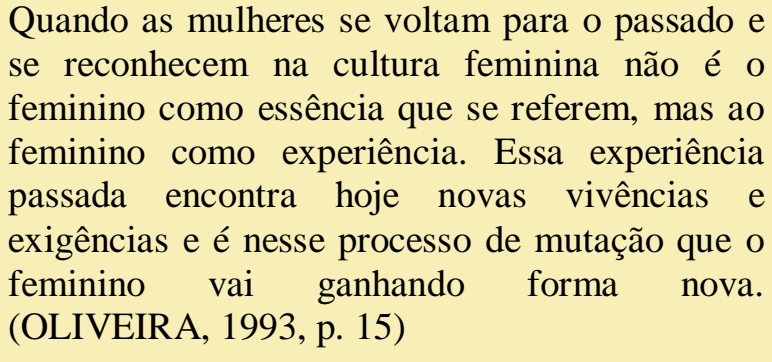

Oliveira assinala que o feminismo não foi apenas um fato cultural, mas, sobretudo, um fator de cultura. Transformou o pessoal em político e, para desmontar a dicotomia macho (positivo) x fêmea (negativo), começou por desestabilizar certezas conceituais, desautorizando o discurso hegemônico. O tópico família foi forte alvo de desconstrução feminista porque nele a simbologia da menos valia feminina era reiterada pelos ritos nos quais se reafirmam as estruturas de dominação.

As regras de casamento fundam a relação de assimetria social radical entre os sexo. (...) Um homem só pode obter uma mulher do outro homem (pai) (...). Para as mulheres, ao contrário, a troca acarreta sua redução ao status de objeto: não passam de moeda de troca, signos e 
${ }^{3}$ Haveria um esquecimento semiconsciente, no qual escolhe-se um termo e refuta outro e um esquecimento ideológico que consiste um esquecimento ideológico que consiste no acionamento na memória de discursos preexistentes. Para a Análise do Discurso Francesa o esquecimento é estruturante já que permite a constituição dos sujeitos que esquecem o já dito e se identificam como o que dizem se constituindo como tal.

4 Na verdade, a Análise do Discurso Francesa nem acredita em escolhas conscientes, acredita que os discursos nos atravessam. Eu, entretanto, me situo
teoricamente numa flexibilização do conceito de esquecimento porque acredito que existem momentos de menos assujeitamento da pessoa que fala e escreve. Desse modo, embora utilize conceitos como memória discursiva, esquecim ao que chamo Teorias do Discurso.

É parte de minha licença Sabática iniciada em março de 2014 com previsão de término em agosto. emblemas dos status dominante dos homens.(OLIVEIRA, 1993, p. 32-33)

Em Um mundo novo em gestação, Rose Muraro (2003) além de denunciar a cultura patriarcal como forte aliada do capitalismo que empobrece o mundo e devasta o planeta, apresenta os movimentos sociais liderados por mulheres como vetores de um novo modo de gestar baseado na partilha e solidariedade. Desse modo, a autora retorna ao conceito de cultura feminina e parte de exemplos históricos:

Desde a década de 1970, elas começaram a entrar no mundo público_ não nos partidos e nas manifestações tradicionais, mas em formas novas de organização, chamadas movimentos sociais. (...) Nesses movimentos as decisões fazem-se de baixo para cima, por consenso. Todos têm vez e voz, e o poder é um serviço (p. 45-46).

Apoiadas no conceito de cultura feminina esta vertente feminista acredita que os estudos de gênero devem ser bem mais do que o apontamento de marcas discursivas que compilam uma memória discursiva que engendra nosso entendimento do que seja o masculino e o feminino. A crítica feminista, nos estudos literários, aposta que dar visibilidade as idéias tecidas em tramas ficcionais de autoras brasileiras é permitir que as mulheres atuem na vida cultural do país e exerçam seu papel político de intervenção social, à medida que o longo aprendizado na cultura feminina pode, além de denunciar formas de violência sustentadas pelos discursos hegemônicos, sobretudo, potencializar a autonomia do ser humano, desautorizando desigualdades.

\section{O tópico casamento em narrativas femininas}

Das três autoras estudadas (a saber: Marina Colasanti; Ana Miranda e Kátia Borges), apenas Colasanti é declaradamente feminista, mas o conceito de formação discursiva da Análise do Discurso Francesa e sua contrapartida dos tipos de esquecimento ${ }^{3}$ nos permitem afirmar que nossos discursos articulam vozes que vão além de nossas escolhas conscientes ${ }^{4}$. Portanto, minha análise das contistas procura cruzamentos entre as vozes postas em cena (narradoras e personagens) pelas autoras e a temática de gênero e o ideário feminista.

Neste artigo que é apenas um recorte de uma pesquisa inconclusa $^{5}$, seleciono apenas um conto de cada autora estudada para o que chamo de análises iniciais das obras em estudo. Nosso recorte 
${ }^{6}$ Num trabalho sobre poetisas cariocas na entrada do século XXI, observo em quatro autoras que "todas colocam, na cena poética, mulheres (ficcionais e reais) que enxergam sua identidade construída e/ou fragmentada a partir do universo privado" (BARBOSA, 2001)

\section{Adriana Maria de Abreu Barbosa}

aqui se fez pela presença explicita do tema casamento nos contos escolhidos. Sendo assim proponho uma análise embasada em conceitos da Crítica Feminista e das Teorias do Discurso dos contos "Nunca tiveram muito a se dizer" (Marina Colasanti, 1986); Ausência (Ana Miranda, 1999) e "Um céu de chumbo" (Kátia Borges, 2012).

Dizer contos breves significa que este gênero literário característico por uma forma abreviada de narrativa pode ser ainda mais sucinto (como é o caso das obras analisadas) e atender as características estruturais próprias ao conto que é ser uma amostragem, como um flagrante ou um episódio representativo (SOARES, 1999). No caso dos três contos escolhidos, as autoras tomam uma cena do cotidiano familiar como amostragem do casamento e tem por episódio representativo, respectivamente: em Colasanti, uma festa de Bodas de Ouro; em Ana Miranda, a observação dos objetos da casa e em Kátia Borges, um telefonema. Mais uma vez a escrita de autoria feminina toma o universo do mundo privado ${ }^{6}$, a casa, como local de ambientação do conto. E de dentro das casas surgem personagens femininas em crise. Os três contos narram famílias em desencontro, por motivos diversos, mas todos da ordem das relações interpessoais. Todos revelam casamentos em crise, marcados, sobretudo, pelos silêncios. E a leitura dos contos não é animadora, convida o leitor a entrar numa ambiência de finitudes e desesperança, pois as famílias ali retratadas parecem não ter "cura". Desse modo, esses contos assinados por escritoras parecem ter consonância com a proposta do Feminismo da Diferença que nos idos de 80 afirmava que:

$$
\begin{aligned}
& \text { O futuro do movimento é angustiar a sociedade, } \\
& \text { deparando-a com os problemas que, até agora, as } \\
& \text { mulheres tentaram resolver sozinhas. } \\
& \text { Transformar a neurose das mulheres em neurose } \\
& \text { social é o recurso terapêutico de que elas terão de } \\
& \text { lançar mão (OLIVEIRA, 1993, p. } 89 \text { ). }
\end{aligned}
$$

\section{Nunca tiveram muito a se dizer}

Com título auto-explicativo, o enredo do conto trata da quebra do silêncio inesperada entre um casal, na festa de bodas de ouro organizada pelos familiares. O narrador nos orienta que "Não se falavam. Desde a noite de núpcias, quando olhando o corpo recémpossuído ele se expressara de forma pouco nobre, ela deixara de lhe dirigir a palavra." O ponto de vista escolhido é o da terceira pessoa onisciente, mas não intrusa. $\mathrm{O}$ narrador descreve o que vê 
(focalização externa), mas sabe dos sentimentos dos protagonistas (focalização interna): o casal.

Os personagens não têm nomes, o narrador se refere ao casal como ele e ela. Os demais personagens são identificados pelo grau de parentesco: filhos, noras e netos. Sem identificações, o texto sugere que poderia ser qualquer família, mas dentro de um padrão familiar. Em pista explícita, o uso da palavra patriarcas, para se referir ao casal homenageado pela comemoração, autoriza-me a pensar que o padrão narrado é o de uma família patriarcal.

A ênfase nas núpcias, o termo "corpo possuído" e a associação de grosseria ao homem (atenuada pelo eufemismo "forma pouco nobre") ajuda ao leitor a ambientar a família narrada em tempos passados, nos quais a vida sexual da mulher deveria começar no dia do casamento. Ratifica a suspeita de um pertencimento a formação discursiva (FD) patriarcal a atitude masculina prevista também nos códigos patriarcais, nos quais o homem é o ativo no sexo e a mulher passiva (a coisa a ser possuída) também ali representada na narração. Além disso, outros atributos tradicionais do feminino e do masculino, por oposição, são postos em cena: frente à rudeza do masculino; a delicadeza do feminino se fecha em silêncios.

Dossiê Expressões Artísticas e Mulheres
Da noite de núpcias (que não teve final feliz), o conto salta cronologicamente para o dia da celebração de bodas de ouro, isto é, 50 anos após, quando o marido é surpreendido pela esposa que lhe chama pelo nome, quebrando o silêncio.

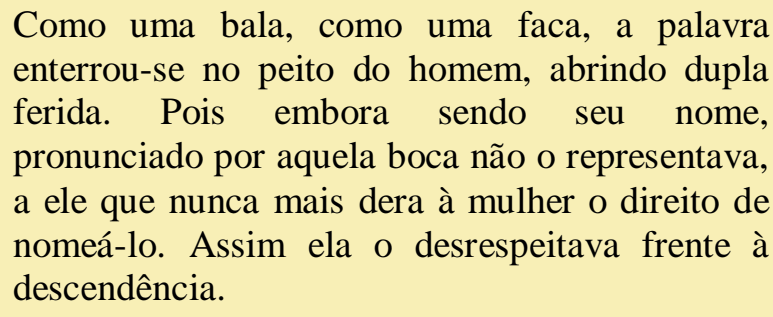

Mais uma vez o léxico escolhido retoma o ideário da família patriarcal em que a assimetria das relações dava ao homem o pátrio poder sobre mulher e descendentes. E o silêncio da mulher, que no primeiro parágrafo pareceu reação e escolha própria, agora é apresentado como coação do homem. Entretanto, o agressor (aquele que se expressava de forma pouco nobre e que a proibira de nomeálo, isto é, a silenciou) sentiu-se agredido pela liberdade da mulher em falar-lhe mesmo sem permissão. A personagem feminina sai da passividade esperada e utiliza a palavra trocada como arma contra o outro. Assim como o silêncio foi o que consagrou e provavelmente assegurou a duração do casamento, o uso da palavra desestabiliza o contrato familiar. Sendo assim, a escrita de Colasanti suscita um 
desfecho inesperado, no qual o agressor revida também com palavras:

\begin{abstract}
Pálido, apoiou-se com as mãos espalmadas sobre o tampo de mármore, e num impulso assassino revidou, sibilando entre dentes o nome da mulher. Ela cambaleou, levou a mão à boca como quem ampara uma golfada de sangue. Mas já a família batia palmas, e a sala toda estremecia ao som do coral doméstico que entoava Parabéns pra Vocês.
\end{abstract}

O silêncio como alegoria é o apelo da estética do texto para causar estranhamento. O leitor se pergunta: como poderiam viver sem se falar tantos anos? Logo, esse silêncio exige deciframentos menos literais "já que uma alegoria em Literatura é uma forma especializada de narrativa simbólica, que não apenas sugere algo além de seu sentido literal, mas insiste em ser decodificada em um outro sentido" (LODGE, 2011, p.150). Quebrar o silêncio foi ato de rebeldia que podia botar a perder todo um contrato de casamento que perdurava há 50 anos. Golpeados pelas palavras os protagonistas são salvos, de certo modo, pela família que se mantém no script da comemoração, alheia aos reais sentimentos do casal. Afinal, como sugere o conto, na família patriarcal o silêncio é de ouro e esconde/preserva infelicidades incontáveis.
Desse modo, o conto coloca em cena duas formações discursivas, uma representante do ideário patriarcal, emoldurada pelos papéis sociais de pai, mãe, genro, nora e filhos e pelo evento festa, evocando alegria, vitória e celebração do que perdura. Por outro lado, o sentimento da esposa na noite de núpcias, o silêncio travado entre o casal e, por fim, o dilaceramento causado pela palavra trocada, denuncia uma formação discursiva que questiona à família patriarcal, logo uma FD anti-patriarcalismo que desautoriza a família e a coloca sob suspeita. Há vestígios de uma FD feminista.

\section{Ausência}

Em Ausência, Ana Miranda adota o ponto de vista da narradora. A história contada em primeira pessoa tem como enredo o vasculhar pela casa à procura do marido que a narradora pensa já ter partido, conforme ela mesma anuncia no primeiro parágrafo: "Tenho a sensação de que ele se foi, partiu, cada dia partiu um pouco mais até se tornar invisível”.

A casa e seus objetos são descritos por um texto de sintaxe atropelada por um encaixar de sentenças unidas por vírgulas com poucos ou quase nenhum conectivo, como se a mente da 
protagonista fizesse a revista no ambiente, ou ainda, como se a boca falasse o que olho via.

A invisibilidade/ausência do amado provoca uma atmosfera de falência e decrepitude pelo uso de adjetivos como "camisas vazias de corpo"; "cabides como esqueletos de gente morta"; "um perfume de mofo".

A antítese entre a presença dos objetos pessoais e a ausência do dono confunde a busca da personagem: "busco a prova de que ele se foi talvez para sempre, mas as estantes repletas de seus livros, a chave do carro no chaveiro, o casaco de couro no cabide...".

$\mathrm{O}$ embate entre a presença dos objetos do marido e a ausência da pessoa dele é descrita na seqüência seguinte:

Tudo continua existir, mas ele se foi, sua voz não mais me escuta, seu cheiro desapareceu, começo a me esquecer do seu rosto, ressoa o seu caminhar silencioso de noite pela casa quando eu ouvia o ruído delicado de seus ossos a estalar, apenas ele caminha como um fantasma que vive em outro mundo e não me vê, eu o chamo ele não ouve, nossos corpos se cruzam, se penetram e não se tocam...
Aqui a alegoria da ausência constrói uma atmosfera semelhante a do silêncio no conto de Colasanti. Se neste o afastamento se deu de imediato após a noite de núpcias, a narrativa de Ana Miranda nos conduz para um afastamento gradativo. O amado vai sumindo aos poucos.

Embora busque pelo marido através das coisas da casa, a narradora parece resignada em manter o script do casamento já que, como ela informa ao final do conto "faço uma salada de frutas, um café, preparo figos descascados, uma taça de vinho e acendo uma vela ao jantar, jantamos em silêncio, sem olhar um para o outro". Desse modo, exercer o papel social de esposa, com as funções a ele relacionadas na perspectiva patriarcal está acima da felicidade e desejos individual. O casamento, em Ausência, mata as pessoas, mas salva os papéis e, conseqüentemente, a instituição família.

A voz reclamante é a do feminino, visto que o masculino já está ausente. Na perspectiva ficcional da autora, cabe á mulher, mesmo insatisfeita, a manutenção do funcionamento da casa e do casamento.

A ausência em presença do marido do modo como é descrito em angústia pela narradora coloca em cena um discurso que avalia 
negativamente o casamento como encontro afetivo. Na verdade, a busca é pelo amado, pois o marido ainda senta à mesa mesmo em silêncio. Todavia, o final condescendente prevê a manutenção dos ritos, reforçando o caráter institucional da família. De novo são postos em cena um discurso anticasamento, a voz decepcionada de alguém que espera mais do que consegue obter do contrato e um discurso neutralizado pela permanência das ações que preservam o matrimônio.

Mais uma vez o final não é feliz e as histórias de amor escritas pelas autoras desmentem os contos de fada e a formação discursiva por eles veiculada e cristalizada pela cultura patriarcal do axioma "foram felizes para sempre". Além disso, o conto sugere que no universo do privado, a mulher reina sobre as coisas, mas não sobre os afetos: desfaz-se de certo modo o mito da rainha do lar. A rainha em questão parece um pouco destronada, decepcionada, ela não é vista, ouvida, notada, sentida. Mais uma vez a leitura é um convite ao desassossego. Desestabiliza-se o conceito do casamento como porto seguro. Desse modo, em "Ausência", a solidão é tópico associado à vida a dois, e por isso suspeita-se de uma FD anticasamento e muito aproximada do que afirmava o feminismo da diferença quando sugeria "levar a pauta do mundo privado ao público", ou ainda, transformar a neurose das mulheres em neurose social.

\section{Um céu de chumbo}

Em "Um céu de chumbo", conto que encerra o recém lançado livro Escorpião Amarelo da autora Kátia Borges, mas uma vez o tema casamento será desnudado de ilusões. Uma personagem feminina revela-se acomodada aos papéis de esposa e mãe, mas terá seu mundo desorganizado por um telefonema.

O início do conto sugere que a manutenção da família seja algo relativamente acordado já que como informa o narrador: "Tudo parecia perfeito quando o telefone tocou em uma manhã remelenta de domingo. O marido ainda dormia, e os filhos faziam uma algazarra dos diabos no jardim."

O uso da modalização parecia no lugar de estava antecipa o clima sugerido pelo título do conto "Um céu de chumbo" que será avistado pela personagem imediatamente ao atender o telefonema (o episódio exemplar escolhido pela autora para construção do enredo) O narrador onisciente revela os pensamentos da protagonista:

Ela atendeu e enquanto falava, percebeu que nuvens escuras_ vindas do nada_ estavam se 
adensando sobre a sua casa. Logo, logo, choveria. Pensou em chamar os meninos para dentro, mas havia esquecido momentaneamente os seus nomes.

Assim como Colasanti e Miranda, Kátia Borges não dá nomes aos personagens que são apresentados apenas como um homem, uma mulher e os meninos, isto é uma família qualquer, ou qualquer uma, ou ainda, um padrão de família. Esse padrão é acompanhado pelos hábitos e costumes: no domingo o marido dorme até mais tarde e as crianças fazem bagunça. A própria descrição de domingo em família como remelento, uma analogia a preguiça e ao fazer nada e dormir muito são hábitos de muitas famílias, tendo o domingo como dia de descanso.

Entretanto, essa formação discursiva de um padrão familiar será ameaçada pela descoberta de uma vida anterior ao casamento. Fato sugerido pelo diálogo relatado pelo narrador:

Uma amiga de infância estava doente. Era urgente ajudar. O homem olhou meio de banda. Conhecia todas as amigas da mulher. Qual delas? Empalideceu. Não havia como explicar. A existência da desconhecida traçava uma linha divisória. Se pudesse olhar para dentro dela, naquele momento, ele teria vertigem
O desconforto como marca de uma estética de denúncia está metaforizado no céu que se acinzenta, numa mudança de atmosfera, mas também há uma mudança nas personagens; a mulher empalidece e o homem poderia ter vertigem caso a olhasse por dentro. Somos conduzidos por este narrador onisciente e tendencioso a contar a história na perspectiva feminina. Apesar de revelar a dúvida do homem, o narrador parece mais solidário e próximo aos sentimentos da personagem, portanto nos antecipa um fim, posterior ao conto: "Também não acreditava ser fácil retornar". Ao revelar o sentimento da personagem enquadra os enunciados seguintes como pista de uma separação:

$$
\begin{aligned}
& \text { Assim quando beijou os filhos, o fez com } \\
& \text { intensidade redobrada. O mesmo se deu quando } \\
& \text { caiu nos braços do marido, na noite anterior à } \\
& \text { partida. Devia muito a eles e a gratidão costuma } \\
& \text { revestir o amor com predicados inomináveis. }
\end{aligned}
$$

Guiados pelas sugestões do narrador a partir dos sentimentos da protagonista, os leitores sentem o desarrumar dos acordos tácitos da família pelo reaparecimento de uma mulher que fez parte do passado da mesma. E mais, é sugerido que a gratidão no caso do 
conto "Um céu de chumbo" não será suficiente para a manutenção do casamento.

Se no conto de Colasanti os parentes cantando parabéns emolduram e garantem o perpetuar da cena, assim como em Ana Miranda, o fazer diário das tarefas cotidianas aprisionam aquela mulher à casa; em Kátia Borges, o telefonema causará o rompimento. A nostalgia que sustenta a mulher em "Ausência" apenas embala a despedida da protagonista em "Um céu de chumbo".

A transgressão é dupla em Kátia Borges porque a família será abandonada por um amor do mesmo sexo. Diante do cardápio proposto pela família patriarcal que prevê maridos e filhos, abre-se uma nova possibilidade de rever um amor do passado e um amor por outra mulher. Esse perfil do feminino transitando por uma sexualidade e afetividade menos convencional está previsto em Badinter para quem:

Alternando, à vontade, papéis masculinos e femininos de acordo com os períodos da vida ou os momentos do dia, elas não têm o sentimento de que sua bissexualidade, seja uma ameaça para sua identidade feminina; ao contrário, sentem a alteridade como a condição de uma existência mais rica e menos determinada previamente (Apud OLIVEIRA, 1993, p. 95).

Essa androginia já fora por mim observada na obra poética de Kátia:

Há também muita indefinição nas marcas de gênero e já não é possível afirmar em todos os poemas se o eu lírico e menino ou menina (...) Na maioria dos outros poemas do livro De volta a casa de abelhas, o gênero está invisível e reflete o que já anunciava o poema "Meninos": "E eu nem sabia o meu sexo." (BARBOSA 2011(c), p. 99)

Assim, atender o chamado da amiga e poder inclusive não voltar para casa constrói no mundo da ficção uma FD em consonância com o ideário feminista que questionou a fixidez do destino da mulher atrelado apenas ao corpo biológico e sua suposta função primeva da procriação.

Distante do ideário dos contos de fadas, as mulheres ficcionais postas em cena pelas contistas aqui estudadas não nos asseguram o final feliz e muito menos que a presença do masculino seja a real condição da felicidade. Em Colasanti, o homem decepciona desde a 
noite de núpcias, marcando um desencontro de vida inteira. Em Ana Miranda a mulher sofre de ausência e vive uma solidão a dois. E por fim, em Kátia Borges, nem o homem, nem os filhos, nem mesmo o "domingo remelento" (que inspira alguma paz) impedira o desejo feminino de transgredir. Neste sentindo, conforme suspeitei ao escolher o corpus, essas autoras trabalham a literatura num viés da crítica social com forte embasamento na crítica feminista, já que: o feminismo propõe uma pluralidade de projetos e de identidades a serem inventadas no lugar de um único molde a ser imitado e, para isso, foi preciso atacar princípios estruturantes da ordem estabelecida. Neste recorte de corpus de contos de autoria feminina, vê-se concretamente o ataque a instituição família nos moldes do casamento tradicional.

\section{Ainda somos feministas}

$\mathrm{O}$ ataque ao casamento tradicional na família patriarcal que separa a casa em dois mundos um masculino (ativo) e outro feminino (passivo) aqui analisado em três tempos: na década de 80 por Colasanti, na década de 90 por Ana Miranda e na primeira década do século XXI por Kátia Borges, me parece atual e urgente.
O ideário que credita a mulher o papel de possuída e conseqüentemente ao homem o papel de possuidor é permissivo de todo tipo de violência (da simbólica à física) com a qual se convive diariamente. São muitas as manchetes de jornal que noticiam as vinganças sangrentas de namorados e maridos que não aceitam o desejo de separação das mulheres. No papel de donos se sentem com direitos sobre a coisa possuída incluindo o direito de retirar a vida.

Nas narrativas das autoras aqui apresentadas, a violência simbólica representada pelos silêncios, decepções, ausências, segredos e um cotidiano de rituais repetidos sem muita reflexão atingem o leitor que é certamente contagiado pelos sentimentos das personagens. Em "Nunca tiveram muito a se dizer", o silêncio, quando quebrado, revela a mágoa guardada transformada em ira. Em "Ausência", a narrativa com pontuação frouxa fala da melancolia e fadiga da busca pelo outro que nunca é alcançada, transbordando uma atmosfera de solidão. Já em "Um céu de chumbo", a aparente normalidade da vida a dois e suas conveniências e contratos serão trocados pela paixão. Mas como é uma paixão fora dos padrões convencionais, o leitor é surpreendido sendo colocado, junto à protagonista, fora de uma suposta zona de conforto. A mim parece impossível sair da leitura desses contos sem 
um forte desejo de repensar a vida, as identidades e, sobretudo, as relações.

De estética mais conservadora, Colasanti mantém o enredo contado por um narrador neutro que apresenta o episódio construído na tradicional sequiência narrativa com a presença de um clímax (a palavra inesperada da personagem) e um desfecho que retoma ao início da narrativa. Portanto, a estética do conto refrata a temática ilustrada: tudo deve permanecer onde sempre esteve, apesar da dor.

Já em Ana Miranda, a melancolia e o cansaço da busca estão retratados pela sintaxe sem pontos (a não ser o final e único) que obriga o leitor a ficar sem fôlego. Desse modo, como leitores, somos convidados a experimentar o desconforto da vida aparentemente organizada como a mesa do café posta no desfecho do conto.

Kátia Borges mantém a estética das seqüências narrativas com presença de clímax (a pergunta do marido sobre a desconhecida que faz a personagem empalidecer). A surpresa está garantida pelo desfecho em aberto e a possibilidade de não retorno a seqüência inicial, isto é a cena familiar de domingo. O tema da bi/homossexualidade apenas sugerido é tópico que provoca o questionamento da heterossexualidade como norma conseqüentemente ameaça a família patriarcal.

Se uma leitura feminista é aquela que propõe examinar o mundo pela ótica da cultura do feminino (como um aprendizado e não uma essência), mais uma vez a Literatura de autoria feminina brasileira assume seu papel de dar visibilidade a esse modo de enxergar a realidade. A proposta das autoras é um convite a enxergar o casamento sem ilusões. E se na década de 80 e 90 só era possível denunciar e lamentar, tendo em vista que os papéis pareciam acima das pessoas, na ficção de Kátia Borges, na entrada do século XXI, ousa-se um pouco mais: ousa-se colocar a pessoa e seus desejos acima dos papéis, ao menos é o que sugere a protagonista do conto. Neste sentido, a ousadia da personagem está em consonância com as sociedades liquidas nas quais o prazer estaria acima do dever.

Como leitora e mulher envolvida pela temática, herdeira de uma geração que abriu mão do mundo privado para pertencer ao mundo público, pergunto-me quais outros caminhos seriam ainda possíveis, fora do eixo prazer $\mathrm{X}$ dever, de certo modo ainda freudianos entre Eros e Thanatos. De visão mais holística e utópica gostaria de sair das dicotomias e aguardo ansiosa na Literatura e nas Artes visões de um novo mundo no qual os binômios masculino/ 
feminino, prazer/dever, estejam integrados. Para mim, nem o aprisionamento aos papéis fixados para o feminino e masculino proposto pela heteronormatividade e nem mesmo a saída aparentemente fácil da identidade líquida e sem projetos são ainda satisfatórias soluções.

Como já afirmamos em trabalho anterior (BARBOSA, 2010), acreditamos que um outro mundo é possível pois parte da superação da cultura Patriarcal já vem sendo realizada pelo movimento feminista. Se houve um tempo em que os crimes de honra eram legitimados pela sociedade dando ao marido direito de tirar a vida da esposa, caso suspeita-se de traição, hoje a Lei Maria da Penha pune qualquer agressor.

Para pensar o papel da literatura nessa discussão podemos nos referir um episódio da obra de Jorge Amado (só para citar algum), escrita na década de cinqüenta (mas remetendo-se a cidade de Ilhéus na década de 30) no romance Gabriela. O autor pune o coronel que mata a esposa, valendo-se de um discurso progressista trazido pela nova liderança política na figura de um personagem vindo do sudeste do país:

Algum tempo depois, o coronel Jesuíno Mendonça foi levado a júri, acusado de haver morto a tiros sua esposa Dona Sinhazinha Guedes Mendonça e o cirurgião-dentista Osmundo Pimentel, por questão de ciúmes (...) Dr. Ezequiel Prado, emocionante: já não era Ilhéus terra de bandidos, paraíso de assassinos (...) Seu tema foi a civilização e o progresso. Pela primeira vez, na História de Ilhéus, um corone do cacau viu-se condenado à prisão por haver assassinado esposa adúltera e seu amante (AMADO, 2012).

O discurso literário acena para duas realidades e conseqüentemente, duas formações discursivas e ideológicas: denuncia a Bahia coronelista (FD patriarcal) e acena para a construção de uma Bahia progressista (FD anti-patriarcal) e, de certo modo, antecipa o que viria ser uma lei no Brasil. Daí creditarmos a literatura um importante lócus de tecnologia de gêneros.

Sonho ainda com um Brasil onde não haja violência de gênero e a lei seja cada vez menos necessária para a manutenção do óbvio: o direito à vida de homens e mulheres independente de sua orientações sexuais e identidades de gênero. 


\section{Referências Bibliográficas}

AMADO, Jorge. Gabriela, Cravo e Canela. Crônica de uma cidade do interior. 2 ed. São Paulo: Companhia das Letras, 2012.

BARBOSA, Adriana Maria de Abreu. Ficções Do Feminino. Vitoria da Conquista: Edições UESB, 2011.

"Modos de ver ler e escrever no século XXI." Litterata, v. 1, N. 2 jun./dez. 2011(b).

"(Re) visões de gênero: escritoras na imprensa brasileira."

In: CUNHA, Helena Parente (Org.). Violência Simbólica e estratégias de dominação. Rio de Janeiro: Editora da Palavra\& Programa de Pós graduação em Ciência da Literatura da Faculdade Letras da UFRJ, 2011(c),

"Educação e desenvolvimento integral da pessoa humana: um caminho para a paz". In: ALMEIDA, Jorge Miranda de (Org.). Pressupostos da educação para uma cultura ética da paz. São Paulo: Companhia ilimitada, 2010.

"Transgressão, identidade feminina e outrocidade na poesia marginal de Ana C.”. In: CUNHA, Helena Parente. (Org.).
Desafiando o cânone. Aspectos da literatura de autoria feminina na prosa e na poesia. Rio de Janeiro: Tempo Brasileiro, 1999.

"O feminismo atualizado na poesia de Valéria Villela, Teresa Cristina Meirelles Oliveira, Sandra Fernandes, Beatriz Scorcio Chacon.” In: CUNHA, Helena Parente (Org.). Além do cânone. Vozes femininas e estreantes na poesia dos anos 90. Rio de Janeiro: Tempo Brasileiro, 2001.

BAUMAN, Zygmunt. Modernidade Líquida. Rio de Janeiro: Jorge Zahar Ed, 2001.

COLASANTI, Marina. Fragatas para terras distantes. Rio de Janeiro: Record, 2004.

CUNHA, Helena Parente (Org.). Violência Simbólica e estratégias de dominação. Rio de Janeiro: Editora da Palavra\& Programa de Pós-graduação em Ciência da Literatura da Faculdade Letras da UFRJ, 2011.

HEINE, Palmira. Tramas e temas em Análise de Discurso. Curitiba: Editora CRV, 2012 
JUNQUEIRA, Rogério Diniz. "Pedagogia do armário e currículo em ação: heteronormatividade, heterossexismo e homofobia no cotidiano escolar." In: MISKOLCI, Richard; PELÚCIO, Larissa (Orgs.). Discurso fora da ordem: sexualidade, saberes e direitos. São Paulo: Annablume; FAPESP, 2012.

LAURETIS, Teresa de. "A tecnologia do gênero." In: HOLANDA, Heloísa Buarque de (Org.). O feminismo como crítica da cultura. Rio de Janeiro: Rocco, 1994.

LEITE, Ligia Chiappini Moraes Leite. O foco narrativo. 3ed. São Paulo: Editora Ática, 1987.

LOGDE, David. A arte da ficção. Porto Alegre: L\&PM, 2011.

LOURO, Guacira Lopes. Gênero, Sexualidade e educação. Uma perspectiva pós-estruturalista.11ed. Petrópolis, RJ: Vozes, 2010.

MURARO, Rose. Um mundo novo em gestação. Campinas: Verus, 2003.
OLIVEIRA, Rosiska Darcy de. Elogio da diferença: o feminismo emergente. 3. Ed. São Paulo: Brasiliense, 1993.

SCOTT, Joan. Gênero: uma categoria útil para análise histórica. Tradução: Christine Rufino Dabat \&Maria Betânia Ávila. Gender: a useful category of historical analyses. Gender and the politics of history. New York, Columbia University Press, 1989.

SOARES, Angélica. Gêneros Literários. 5. ed. São Paulo: Editora Ática, 1999.

WOOLF, Virgínia. Um teto todo seu. Trad. Vera Ribeiro. Rio de Janeiro: Nova Fronteira, 1985. 